\title{
Effects of Tannery Wastes on the Fattening of Growing Cattle, Carcass, and Meat Quality
}

\author{
Md. Jahangir Alam ${ }^{1,2}$, Md. Mufazzal Hossain², Md. Anwarul Haque Beg², Ki-Chang Nam¹, and Sang-Suk Lee ${ }^{1}$ \\ ${ }^{1}$ Dept. of Animal Science \& Technology, Sunchon National University, Jeonnam 540-742, Korea \\ ${ }^{2}$ Dept. of Animal Husbandry, Sher-e-Bangla Agricultural University, Dhaka, Bangladesh
}

\begin{abstract}
The present study was conducted to determine the effect of tannery waste protein concentrate (TWPC) on fattening of cattle and the carcass and meat quality, with the aim of replacing the costly commercial protein concentrate (Jasoprot) with a more economical and effective alternative. Twelve young cattle (six male and six female) were fed during the study period on a control diet (T1) with 10\% Jasoprot and on two test diets: 5\% TWPC $+5 \%$ Jasoprot (T2) and 10\% TWPC (T3). The test diets significantly affected $(p<0.05)$ live weight gain and profitability compared to the control diet, perhaps due to the increased protein and essential amino acid content, relative to Jasoprot. TWPC was free of aflatoxin. Sensory-evaluated organoleptic scores did not differ among the groups. Chemical composition was normal as other beef and was non toxic especially within recommended chromium level $(1.90 \pm 0.6 \mu \mathrm{g})$. Total lipid contents were higher $(p<0.05)$ in T3, and moisture, ash and crude protein contents were almost similar $(p>0.05)$ among the three groups. It is concluded that TWPC or an equal mixture of TWPC and Jasoprot may be an economic and efficient alternative protein source to Jasoprot in the cattle industry, which minimizes adverse effects on carcass and sensory meat quality.
\end{abstract}

Key words: tannery wastes, fattening cattle, carcass, meat quality, protein concentrate

\section{Introduction}

High prices and shortage of feed ingredients are the main constraints involved in animal production. The cost of feed ingredients is increasing at an alarming rate and currently accounts for about $60-65 \%$ of the total cost of animal production, with protein comprising about $13 \%$ of the total feed cost (Banerjee, 1992; Singh, 1990). Indeed, soybean meal, fishmeal and other protein concentrates are becoming very costly. However, a certain amount of protein must be added to the diet to satisfy essential amino acid requirements (Scott, et al., 1976). Tannery wastes are the wastes produced by the tannery industry during processing of hides and skin to leather. Tannery waste consists of excess fat, fascia, fleshings (subcutaneous tissue), and the cutting and splitting portions (unnecessary portions) of hides and skins during processing of leather (Alam, 2001). These materials have been found to contain a large amount of protein (Rao, 2000); therefore, they

\footnotetext{
*Corresponding author : Sang Suk Lee, Dept. of Animal Science \& Technology, Sunchon National University, Jeonnam 540-742, Korea. Tel: 82-61-750-3237, Fax: 82-61-750-3237, E-mail: rumen@sunchon.ac.kr or jangalam@yahoo.com
}

have the potential for use as an inexpensive alternative to currently available protein for the addition to livestock feed.

Tannery wastes causes serious environmental pollution and ecological imbalance. As a result, the proper collection and use of tannery wastes could keep the environment free from pollution. There are 277 tanneries in Bangladesh, where 240 metric tons of hides and skins are processed every day. The Hazaribagh Tannery Industry in Dhaka, which is the capital of Bangladesh, processes 220 metric tons of hides and skins a day, resulting in the production of 8.47 million liters of liquid and 98 metric tons of solid tannery wastes daily (FAO, 1991 cited by Salam and Billah, 1998).

It is important to consider bovine spongiform encephalopathy (BSE) or mad cow disease prior to using tannery wastes in the ration. Obviously, if any area is affected by BSE, it is better to avoid using tannery wastes as animal feed. Conversely, it has been shown that hides and skins are not carriers of this disease agent (Rao, 2000); therefore, there is relatively little risk associated with the use of these materials for livestock development. It has also been shown that many Bangladeshi farmers currently use these tannery wastes as livestock feed, even 
though the feeds are not prepared in a scientific fashion. Tannery wastes are also used in the diet of poultry and cattle in other countries throughout the world, but no studies have been conducted to evaluate the use of tannery wastes in the diet of cattle in Bangladesh.

Therefore, this study was conducted to identify alternate protein sources for cattle and their effects on growth and meat quality, as well as to evaluate the feasibility of the use of tannery wastes as protein source to livestock feed.

\section{Materials and Methods}

\section{Preparation of tannery waste protein concentrate (TWPC)}

Tannery wastes were collected from the Hazaribagh tannery industry area in Dhaka. The tannery wastes were primarily collected from cattle hides and goat skin. Fleshings, which are the excess fat, fascia and flesh removed from the flesh side of the hides and skins were also collected from hides and skins store houses. The trimmings, which consisted of the unnecessary portions of the hides and skins removed during processing, were also collected. Additionally, shavings or splits produced during the smoothing and thickness adjusting stage of dried vegetable tanned leather ( $\mathrm{Cr}$ free) were collected, but these materials were not collected from wet blue leather processing facilities due to the presence of chromium. The method described by Blazej et al. (1969) to make protein concentrate from tannery wastes was modified and employed for the preparation of tannery waste protein concentrate (TWPC) in the present experiment.

After collecting the tannery wastes, fleshings and trimmings were properly washed 2-3 times with clean tap water to remove the salt and dust or other foreign materials. The shavings or splits from the vegetable tanned leather were not washed as they did not contain any undesirable materials. The washed and dried fleshings and trimmings were then cut into small pieces and mixed thoroughly at a ratio of 17:83. The mixed fleshings and trimmings were then added to hot water bath with an equal volume of water and boiled at $100^{\circ} \mathrm{C}$ for $4-5 \mathrm{~h}$ (Fig. 1 ). The shavings or splits were added to a hot water bath with about $50 \%$ of the volume and boiled at $100^{\circ} \mathrm{C}$ for $1-$ $1.5 \mathrm{~h}$. The boiled fleshings and trimmings were then properly mixed with soft shavings or splits on a clean cemented floor at a ratio of 60:40 (Fig. 1). Next, the samples were properly sun-dried after mixing. The dried mixture was then ground using a flour grinding machine.
Finally the ground mixture was sieved through a net containing $2 \mathrm{~mm}$ pores to remove the undesirable particles and hairs. The prepared finely sieved protein concentrate was then packed in the hessian/gunny bags until use.

\section{Preparation of experimental cattle and diets}

A total of 12 young indigenous cattle (6 male and 6 heifers) were divided into three treatment groups (T1, T2 and T3) with four (two male and two female) cattle in each group. The average age of the cattle was one year. The initial average live weight was $149.95 \pm 3.51 \mathrm{~kg}$ for T1 (10\% Jasoprot), $149 \pm 4.29 \mathrm{~kg}$ for T2 (5\% TWPC $+5 \%$ Jasoprot) and $150.1 \pm 4.92 \mathrm{~kg}$ for T3 (10\%TWPC). The cattle were purchased from the nearest market at Asulia Hut, Savar, Dhaka, Bangladesh and housed in a dry shed that was divided into 12 separate pens of equal size (120 $\mathrm{cm} \times 90 \mathrm{~cm}$ ). Each pen was used to house one cow and the feed trial for the experiment was conducted for $75 \mathrm{~d}$.

The diets differed only in the protein feed, they contained rather than protein were wheat bran, rice bran, maize crust, khesari bran, sesame oil cake, di-Ca-phosphate and common salt. T1 received a diet containing 10\% Jasoprot (Jayson Agrovet Ltd., Bangladesh), a commercial protein concentrate (Table 1), T2 received a diet containing $5 \%$ of Jasoprot and $5 \%$ of TWPC, and T3 received a diet containing $10 \%$ of TWPC. The diets administered to the animals are presented in Table 3 .

Through out the experimental period, concentrated feed ( $0.5 \mathrm{~kg}$ in the morning and $1.0 \mathrm{~kg}$ in evening) was supplied to each animal daily according to their treatment. For dry roughage, a total of $1.5 \mathrm{~kg}$ of rice straw per animal mixed with molasses and urea was supplied in two portions each day. The dry roughage was treated by mixing $10 \%$ molasses, $10 \%$ water and $3 \%$ urea with straw and allowing the mixture to stand for $24 \mathrm{~h}$ before providing it to the animals. For succulent, $10 \mathrm{~kg}$ of native green grass were supplied daily to each of the cattle and all animals were provided with fresh clean drinking water ad libitum. For immunization foot and mouth disease (FMD) and anthrax vaccine was applied according to the commonly recognized schedule. In addition, anti helminthes (deworming) medicine was applied after taking the cattle from the market. The cattle pens, instruments and utensils were cleaned and dried daily. Disinfectant and strict bio-security for hygienic measures and sanitation programs were also employed in the experimental house throughout the research period. The different parameters were recorded throughout the experimental periods. The daily feed intake and feed left-over was recorded throughout exper- 


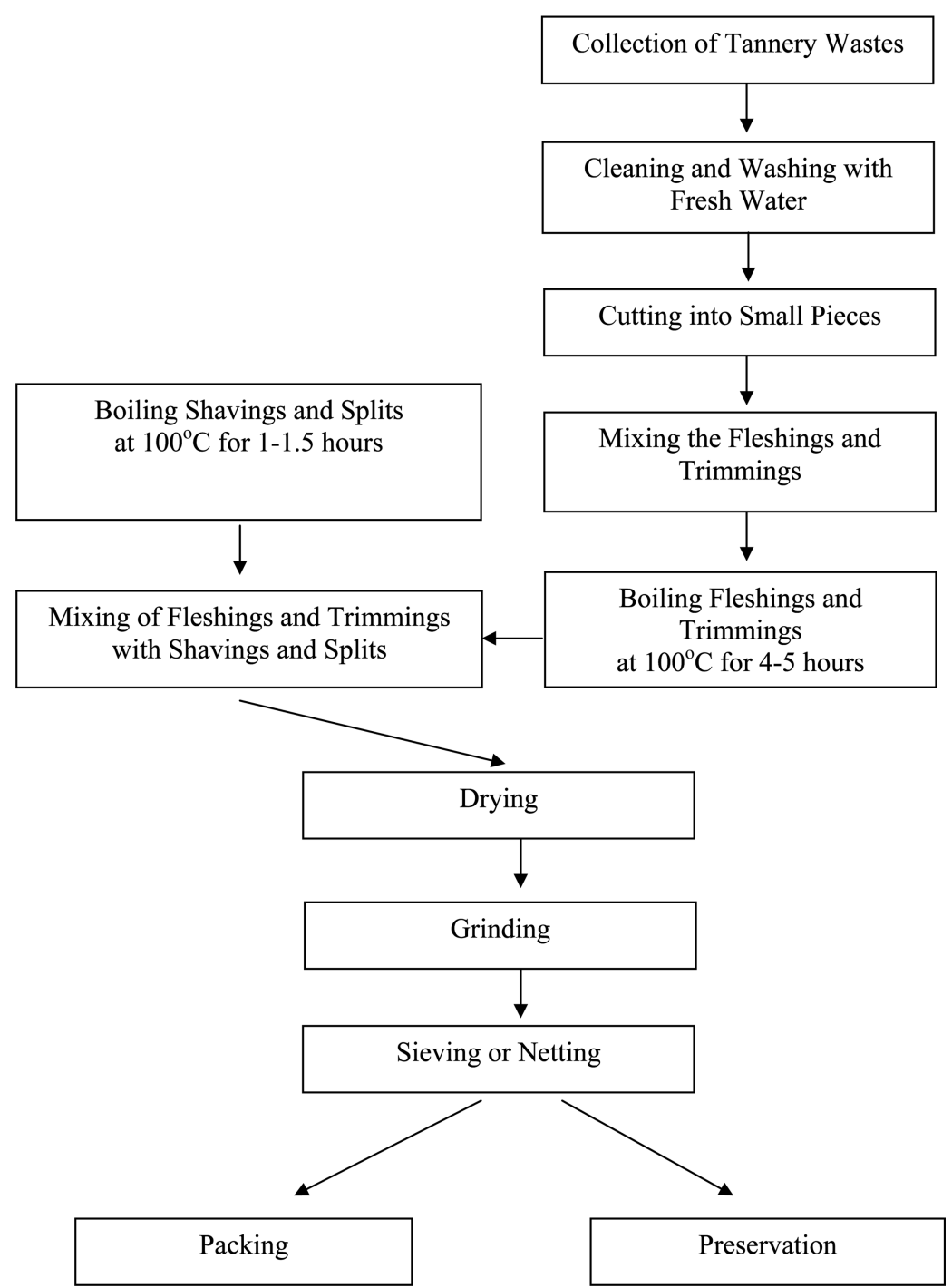

Fig. 1. Schematic Diagram of Tannery Waste Protein Concentrate Preparation.

Table 1. Chemical composition of TWPC and jasoprot

\begin{tabular}{ccccccc}
\hline \hline \multirow{2}{*}{ Items } & \multicolumn{9}{c}{ Composition } \\
\cline { 2 - 7 } & DM (\%) & CP (\%) & ME (Kcal/kg) & CF (\%) & EE (\%) & Ash (\%) \\
\hline TWPC $^{1)}$ & 90.63 & 77.02 & 3450 & 0.77 & 2.83 & 7.19 \\
Jasoprot $^{2}$ & 93.00 & 60.00 & 3230 & 4.00 & 10.00 & 8.20 \\
\hline
\end{tabular}

${ }^{1)}$ TWPC, Tannery waste protein concentrate; ${ }^{2)}$ Jasoprot, Brand name of commercial protein concentrate.

imental period. Moreover, the body weight of each animal was recorded every morning after over night fasting using a digital platform balance.

\section{Analysis of feed}

The feeds used were analyzed in the laboratory of Animal Husbandry at Sher-e-Bangla Agricultural University, Dhaka and Bangladesh Council of Scientific and Industrial Research (BCSIR), Dhaka for determination of the Dry Matter (DM), Crude Protein (CP), Crude Fiber (CF),
Ether Extract (EE), Ash and Metabolizable Energy (ME) (AOAC, 1990). Feed was tested for the presence of aflatoxin in the toxicity laboratory of the Bangladesh Council of Scientific and Industrial Research (BCSIR), Dhaka using an Alisa kit (AOAC, 1990). The amino acid level in the tannery wastes was also determined by HPLC, which was conducted using an Agilent Technologies (1200 series) at the Analytical Laboratory of Degussa-Huls AG, Feed Additives Division, Applied Technology, D-63403 Hanau, Germany. 


\section{Analysis of carcass quality}

The overnight-fasted animals were transported to a commercial slaughterhouse under minimal stress, where they were allowed to rest in a lairage for $12 \mathrm{~h}$. The animals were then immobilized using a knocking method after which they were slaughtered and their carcasses were identified and chilled for $24 \mathrm{~h}$ at $4^{\circ} \mathrm{C}$. The hot carcass weight $(\mathrm{kg})$ was determined immediately after slaughter, before cooling the carcass. After cooling, the right part of the carcass was used to determine the quantitative characteristics. The dressing percentage of each individual animal was defined as the hot carcass weight divided by the live weight.

\section{Analysis of meat composition and toxicity}

The muscles were taken from the loin, back, thigh and abdomen of the slaughtered animals, mixed at an equal weight ratio and then stored at $-20^{\circ} \mathrm{C}$ prior to use. The samples were then grounded, homogenized, and analyzed in triplicate. The beef moisture and ash contents were determined according to the AOAC (Cunnif, 1998). In addition, the crude protein content was obtained using the kjeldahl method (Cunnif, 1998) and the total lipids were extracted using the method described by Bligh and Dyer (1959).

Chromium (VI) toxicity in meat was analyzed using a colorimetric method based on the diphenylcarbazide (DPCZ) reaction (Desjardin et al., 2003). Briefly $50 \mu \mathrm{L}$ of DPCZ solution ( $0.3 \mathrm{~g}$ of chemically pure diphenylcarbazide diluted to a final volume of $500 \mathrm{~mL}$ by adding 100 $\mathrm{mL} 95 \%$ ethanol and $400 \mathrm{~mL}$ of $3.6 \mathrm{~N}$ sulphuric acid) were added to $1 \mathrm{~mL}$ of appropriately diluted sample. DPCZ reacts with chromate to form a purple complex with a maximum absorbance at $540 \mathrm{~nm}$. Samples were periodically collected under sterile conditions and, when necessary, centrifuged before dilution to remove the suspended cells and avoid turbidity. Absorbance measurements were performed using a Spectronic 401 spectrophotometer (France). The total chromium concentration was analyzed $(\lambda=425.4 \mathrm{~nm})$ by flame atomic absorption spectrometry (FAAS) using a Varian Absorption Spectrometer (model 1275).

\section{Meat quality and sensory evaluation}

A sensory test was conducted by the Bangladesh Livestock Research Institute and university teachers from Sher-e-Bangla Agricultural University. Fourteen panels from Sher-e-Bangla Agricultural University and Livestock Research staff with previous experience with meat evaluation participated in the sensory testing. Training sessions were conducted to familiarize panelists with the color (Table 4), texture (Table 4) and marbling (Table 5) point scales to be used, and the range of attribute intensities likely to be encountered during the study. The muscle color after $24 \mathrm{~h}$ of carcass cooling was analyzed according to a point scale (Table 4 ) by the sensory panel test. In addition, the texture was determined based on the size of the fascicle (muscle "grain" size) and evaluated subjectively using a point scale (Table 4 and Table 5).

\section{Statistical analysis}

The results are presented as the means and the standard deviation of the means (Means $\pm \mathrm{SD}$ ). Data were statistically analyzed by one- way analysis of variance (ANOVA) using the COMPARE MEANS procedure (SPSS 7.5., 1999 software for windows, SPSS Inc., Chicago, IL, USA). The least significant difference (LSD) was calculated to evaluate the variations between treatments. $p<0.05$ was considered to be statistically significant.

\section{Results and Discussion}

\section{Chemical composition of prepared protein concen- trate}

The chemical compositions of tannery waste protein concentrate (TWPC) and jasoprot are shown in Table 1. The contamination of aflatoxin in TWPC was found to be negative. In addition, the TWPC (on DM basis) contained more crude protein than jasoprot (Table 1). The crude protein content in jasoprot was $60 \%$, while the TWPC was $77.02 \%$. The composition of TWPC was similar to the values reported by Raju et al. (1997), and Huque et al. (1992), who found that sun dried tannery wastes contained $69.8 \%$ and $68.8 \%$ crude protein, respectively. The essential amino acid contents in TWPC were higher than those of jasoprot (Table 2) and were similar to the values reported by Rao (2000).

Hossain et al. (1998) reported that further work is necessary for development of an effective treatment method for utilizing leather wastes as feed for cattle, fish and other farm animals. The results of the study should help utilize tannery wastes for feed provided to cattle and other farm animals. The texture, color, odor and duration of preservation qualities of TWPC were similar to those of jasoprot. In addition, the nutrient contents of the tannery waste protein concentrate determined in the present study were similar to those described by Rao (2000). 
Table 2. Comparison of amino acid contents of TWPC and Jasoprot

\begin{tabular}{lcc}
\hline \hline Amino acid (AA) & AA in TWPC (\%) & AA in Jasoprot (\%) \\
\hline Lysine & 4.27 & 3.2 \\
Methionine & 1.39 & 0.91 \\
Met+cys & 2.35 & 1.96 \\
Isoleucine & 2.83 & 1.77 \\
Histidine & 1.72 & 1.20 \\
Leucine & 5.27 & 4.26 \\
Phenylalanine & 2.49 & 2.35 \\
Threonine & 3.53 & 2.21 \\
Valine & 3.11 & 2.61
\end{tabular}

Jasoprot, Brand name of commercial protein concentrate; TWPC, Tannery waste protein concentrate.

Table 3. Concentrate feed supplied to the cattle during the experimental period

\begin{tabular}{lccc}
\hline \hline \multicolumn{1}{c}{ Ingredients (\%) } & Diet for T1 & Diet for T2 & Diet for T3 \\
\hline Wheat bran & 20 & 20 & 20 \\
Rice bran & 20 & 20 & 20 \\
Maize crust & 20 & 20 & 20 \\
Khesari bran & 18 & 18 & 18 \\
Sesame oil cake & 10 & 10 & 10 \\
Jasoprot & 10 & 5 & - \\
TWPC & - & 5 & 10 \\
Di-Ca-Phosphate & 1 & 1 & 1 \\
Common salt & 1 & 1 & 1 \\
Total & 100 & 100 & 100 \\
Protein in mixed feed $(\%)$ & 15.64 & 16.37 & 17.01 \\
Energy ME (kcal/100g) in & 257.49 & 258.12 & 258.57 \\
$\quad$ mixed feed & & &
\end{tabular}

T1, Control diet (10\% Jasoprot); T2, 5\% Jasoprot + 5\% TWPC; T3, 10\% TWPC; Jasoprot, Brand name of commercial protein concentrate; TWPC, Tannery waste protein concentrate.
Table 4. Point scale for meat texture and color evaluation

\begin{tabular}{lclc}
\hline \hline \multicolumn{1}{c}{ Texture } & Points & Coloration & Points \\
\hline Very fine & 5 & Cherry red & 5 \\
Fine & 4 & Red & 4 \\
Slightly coarse & 3 & Slightly dark red & 3 \\
Coarse & 2 & Dark red & 2 \\
Very coarse & 1 & Dark & 1 \\
\hline
\end{tabular}

Source: Muller (1987).

\section{Growth performance in cattle}

The daily average live weight gain of cattle in different treatment groups is presented in Table 6. The results revealed that the average daily live weights of cattle were increased rapidly during the experimental period. The initial live weights of cattle were similar among dietary treatment groups (Table 6). At the end of the research period, significant $(p<0.05)$ differences were observed among the different dietary treatment groups. The highest average body weight gain $(530 \pm 40 \mathrm{~g})$ was observed in dietary treatment group $\mathrm{T} 3$, which was followed by $\mathrm{T} 2$ $(510 \pm 40 \mathrm{~g})$ and $\mathrm{T} 1(470 \pm 30 \mathrm{~g})$ in Table 6 . The feed efficiency was also better in $\mathrm{T} 3$ than in $\mathrm{T} 2$ and $\mathrm{T} 1$ (Table 6). These findings indicate that the body weight gain and feed efficiency are correlated.

The findings obtained in the present study agreed with the results of studies conducted by Nedopil et al. (1975), Cenni and Verita (1976), Huque et al. (1992) and Gill et al. (1992). It is also evident from the above findings that the body weight gain of the farm animals was significantly influenced by the replacement of commercial protein concentrate (jasoprot) with TWPC as in dietary treat-

Table 5. Point scale for marbling grade evaluation

\begin{tabular}{lccccccc}
\hline \hline Marbling & Plus & Average & Minus & Marbling & Plus & Average & Minus \\
\hline Abundant & 18 & 17 & 16 & Small & 9 & 8 & 7 \\
Moderate & 15 & 14 & 13 & Light & 6 & 5 & 4 \\
Mean & 12 & 11 & 10 & Traces & 3 & 2 & 1 \\
\hline
\end{tabular}

Source: Muller (1987).

Table 6. Growth performance of cattle in different treatment groups

\begin{tabular}{|c|c|c|c|}
\hline Parameters & $\overline{\mathrm{T} 1^{3)}}$ & $\overline{\mathrm{T}} 2^{4)}$ & $\bar{T} 3^{5)}$ \\
\hline Initial Body Wt. (kg) & $149.95 \pm 3.51^{1)}$ & $149.0 \pm 4.29$ & $150.1 \pm 4.92$ \\
\hline Final Body Wt. (kg) & $185.4 \pm 4.83^{\mathrm{c}}$ & $187.0 \pm 7.39^{\mathrm{b}}$ & $190.35 \pm 4.76^{a}$ \\
\hline Average Daily Gain (g) & $470 \pm 30^{c}$ & $510 \pm 40^{\mathrm{b}}$ & $530 \pm 40^{\mathrm{a}}$ \\
\hline Dry Matter Intake (g) & $2980 \pm 8.16$ & $2945 \pm 9.13$ & $2905 \pm 7.5$ \\
\hline Feed Efficiency or $\mathrm{G} / \mathrm{I}^{2)}(\mathrm{g} / \mathrm{g})$ & $0.16 \pm 0.01$ & $0.17 \pm 0.01$ & $0.18 \pm 0.01$ \\
\hline
\end{tabular}

\footnotetext{
${ }^{\mathrm{a}-\mathrm{c}}$ Means within the same row with different letters are significantly different $(p<0.05)$.

${ }^{1)} \mathrm{Mean} \pm \mathrm{SD} ;{ }^{2} \mathrm{G} / \mathrm{I}$, Average daily gain/dry matter intake; ${ }^{3)} \mathrm{T} 1$, Control diet (10\% Jasoprot), ${ }^{4)} \mathrm{T} 2,5 \% \mathrm{Jasoprot}+5 \% \mathrm{TWPC} ;{ }^{5)} \mathrm{T} 3,10 \%$ TWPC (Jasoprot, Brand name of commercial protein concentrate; TWPC, Tannery waste protein concentrate).
} 
ment groups. Therefore, the higher amino acid values and the protein content likely influenced the weight gain of the cattle.

\section{Chromium toxicity and chemical composition of meat}

Chromium toxicity in the sampled meat was found to be $1.90 \mu \mathrm{g} \pm 0.6 / 1000$ cal. Richard et al. (1992) reported that the acceptable chromium level in meat was up to $2 \mu \mathrm{g} / 1000 \mathrm{cal}$; therefore, the use of the tannery wastes evaluated in this study in feed provided to cattle should not be harmful to humans who consume beef produced by these cattle.

Table 8 shows the chemical composition of beef for groups T1, T2 and T3. The moisture, ash and crude protein contents were similar $(p>0.05)$ among treatment groups. The average moisture content was $73.5 \%$, which is similar to the results observed in other studies (Moreira et al., 2006). In addition, the average ash content was $1 \%$, which is similar to the findings of Prado et al. (2003), Padre et al. (2006) and Brown et al. (2007).

The average protein levels (\%) in groups T1, T2 and T3 were $22.47 \pm 0.19,22.56 \pm 0.10$ and $22.93 \pm 0.15$, respectively. It has been reported (Brown et al., 2007; Padre et al., 2007; Prado et al., 2003) that the average crude protein content ranges from 21 to $23 \%$ in beef. Thus, it can be concluded that the diets provided in this study did not alter the protein levels in the muscles of bovines.

The total lipid content was greater $(p<0.05)$ in the T3 group than in the T1 and T2 groups (Table 8). However, there were no differences $(p>0.05)$ observed in the muscle of groups T1 and T2. In general, the total lipid convert in the muscle of steer is close to $3 \%$ (Prado et al., 2003; Padre et al., 2006, 2007), which is similar to the values observed in the T3 group. However, the total lipid levels observed in all treatment groups were below the maximum level regarded as acceptable for the prevention of diseases related to fat content in beef according to the recommendations from the English Health Department (HMSO, 1994).

\section{Carcass meat quality}

Table 7 shows the final live weight, hot carcass weight, and hot carcass dressing percentage. The hot carcass weight was higher $(p<0.05)$ in the T3 group $(102.21 \mathrm{~kg})$ than in the T2 $(96.46 \mathrm{~kg})$ and $\mathrm{T} 1(89.85 \mathrm{~kg})$ groups. The lowest carcass weight was found in the control group. The amount of useful meat (dressing percentage) obtained from fattening cattle based on hot carcass dressing was greatest $(p<0.05)$ in the T3 group $(53.7 \%)$ followed by the T2 $(51.58 \%)$ and T1 $(50.38 \%)$ cattle groups. The dressing percentage was greater than $50 \%$, which is similar to the results described by Charles and Johnson (1990).

\section{Sensory evaluation of meat}

The results of the sensory test were compiled from the panel test. The observed color point scale for evaluation of meat from the different treatment groups ranged from

Table 7. Carcass characteristics and sensory tests of different treatments

\begin{tabular}{lccc}
\hline \hline \multicolumn{1}{c}{ Parameters } & $\mathrm{T} 1^{2)}$ & $\mathrm{T} 2^{3)}$ & $\mathrm{T}^{4)}$ \\
\hline Final wt. (kg) & $185.4 \pm 4.83^{\mathrm{cl}}$ & $187.0 \pm 7.39^{\mathrm{b}}$ & $190.35 \pm 4.76^{\mathrm{a}}$ \\
Hot carcass wt. (kg) & $89.85 \pm 2.79^{\mathrm{c}}$ & $96.46 \pm 2.17^{\mathrm{b}}$ & $102.21 \pm 1.50^{\mathrm{a}}$ \\
Hot carcass dressing (\%) & $50.38 \pm 0.47^{\mathrm{c}}$ & $51.58 \pm 0.37^{\mathrm{b}}$ & $53.70 \pm 0.25^{\mathrm{a}}$ \\
Color (points) & $3.57 \pm 0.13$ & $3.56 \pm 0.10$ & $3.77 \pm 0.07$ \\
Texture (points) & $4.14 \pm 0.08$ & $3.98 \pm 0.06$ & $4.18 \pm 0.04$ \\
Marbling (points) & $7.14 \pm 0.25$ & $7.68 \pm 0.19$ & $6.95 \pm 0.13$ \\
\hline
\end{tabular}

${ }^{\mathrm{a}-\mathrm{c}}$ Means within the same row with different letters are significantly different $(p<0.05)$.

${ }^{1)} \mathrm{Mean} \pm \mathrm{SD} ;{ }^{2} \mathrm{~T} 1$, Control diet (10\% Jasoprot), ${ }^{3)} \mathrm{T} 2,5 \%$ Jasoprot $+5 \%$ TWPC; ${ }^{4)} \mathrm{T} 3,10 \%$ TWPC (Jasoprot, Brand name of commercial protein concentrate; TWPC, Tannery waste protein concentrate).

Table 8. Chemical composition of muscle from experimental fattening cattle

\begin{tabular}{lcccc}
\hline \hline \multicolumn{1}{c}{ Nutrients } & $\mathrm{T} 1^{2)}$ & $\mathrm{T} 2^{3)}$ & $\mathrm{T}^{4)}$ & Level of significance \\
\hline Moisture (\%) & $74.2 \pm 0.2^{1)}$ & $73.8 \pm 0.11$ & $73.2 \pm 0.10$ & NS \\
Ash (\%) & $1.06 \pm 0.01$ & $1.01 \pm 0.01$ & $1.05 \pm 0.01$ & NS \\
Crude Protein (\%) & $22.47 \pm 0.19$ & $22.56 \pm 0.10$ & $22.93 \pm 0.15$ & NS \\
Total lipids (\%) & $1.71 \pm 0.07^{\mathrm{b}}$ & $1.96 \pm 0.04^{\mathrm{b}}$ & $2.5 \pm 0.05^{\mathrm{a}}$ & $*$ \\
\hline
\end{tabular}

\footnotetext{
$\overline{\mathrm{a}, \mathrm{b}}$ Means within the same row with different letters are significantly different $(p<0.05)$.

${ }^{1)} \mathrm{Mean} \pm \mathrm{SD} ;{ }^{2)} \mathrm{T} 1$, Control diet (10\% Jasoprot), ${ }^{3)} \mathrm{T} 2,5 \%$ Jasoprot $+5 \% \mathrm{TWPC} ;{ }^{4)} \mathrm{T} 3,10 \%$ TWPC (Jasoprot, Brand name of commercial protein concentrate; TWPC, Tannery waste protein concentrate).
} 
Table 9. Comparison of average feed cost in each treatment

\begin{tabular}{|c|c|c|c|}
\hline Feed Ingredients & $\mathrm{T} 1^{2)}$ & $\mathrm{T} 2^{3)}$ & $\mathrm{T}^{4)}$ \\
\hline Wheat bran- & $15 /-$ & $15 /-$ & $15 /-$ \\
\hline Rice bran- & $11 /-$ & $11 /-$ & $11 /-$ \\
\hline Maize crust- & $22 /-$ & $22 /-$ & $22 /-$ \\
\hline Khesari bran- & $12 /-$ & $12 /-$ & $12 /-$ \\
\hline Til(Sesam)oil cake & $35 /-$ & $35 /-$ & $35 /-$ \\
\hline Jasoprot & $60 /-$ & $60 /-$ & - \\
\hline TWPC & - & $3 /-$ & $3 /-$ \\
\hline Di-Ca-phosphate & $50 /-$ & $50 /-$ & $50 /-$ \\
\hline Common Salt & $6 /-$ & $6 /-$ & $6 /-$ \\
\hline $\begin{array}{l}\text { Av. feed cost } / \mathrm{kg} \text { mixed } \\
\text { feed }(\text { Taka })^{1)}\end{array}$ & 26.38 & 23.77 & 19.25 \\
\hline
\end{tabular}

3.56 to 3.77 points (Table 7), and no significant differences were observed $(p>0.05)$. The color scale point indicated that the meat color was slightly dark red to red which was normal based on a study conducted by Charles and Johnson (1990). The observed texture scale points ranged from 3.98 to 4.18 (Table 7). Based on the descriptive evaluation of the panels, the texture of the experimental meat was fine to slightly coarse, and did not differ significantly among groups $(p>0.05)$. The marbling point scale ranged 6.95 to 7.14 , indicating that light marbling was present. The marbling of the meat was also showed insignificant (Table 7). Characteristics of visual observation of the experimental cattle showed similar opinion of Charles and Johnson (1990) and Desjardin et al. (2003) to the above discussions.

\section{Feed cost and profitability}

The average feed cost was low for $\mathrm{T} 3$, while the growth rate was high. $\mathrm{T} 1$ and $\mathrm{T} 2$ had the highest and second highest feed costs, respectively (Table 9), but their body weight gain occupied the second and third position. From this point of view, it was clear that the feed cost of T3 was lowest and that treatment is profitable for cattle rearing (Table 9). These results are in agreement with the findings of Kushak et al. (1990) and Tikhonovskaya and Snitsar (1992) who found a lower feed cost per kg live weight gain, when commercial protein was replaced by tannery waste protein concentrates.

\section{Conclusion}

The TWPC had a significant $(p<0.05)$ effect on live weight gain and profitability when compared to the control diet. Specifically, the body weight gain was higher as a result of the high level of protein and availability of essential amino acids in the TWPC, which is less (protein and amino acids) in jasoprot. Feed conversion efficiency was also found to be better in $\mathrm{T} 3$ than in $\mathrm{T} 2$ or T1. Complete or partial replacement of jasoprot by TWPC led to reduced feed and production cost due to the low cost of TWPC. Additionally, the feed containing tannery wastes did not alter the normal quality of the carcass characteristics and chemical composition of the muscles of fattening cattle. The risk of chromium toxicity was within the recommended levels and contamination of aflatoxin in TWPC was found to be negative. Finally, TWPC or an equal mixture of TWPC and jasoprot may be an economic and efficient substitute for jasoprot as a protein source in the cattle feed. The above findings indicated that tannery wastes can be used efficiently as a substitute for commercial protein concentrate in cattle feed, which will also help reduce environmental pollution.

The present findings will help the livestock farmers formulate rations to obtain good quality carcasses and meats, and will ultimately play a vital role in the control of environmental pollution. However, additional studies and research are needed to enable the use of chrominated tannery wastes.

\section{Acknowledgments}

This project were supported by Ministry of Science and Information \& Communication Technology, Government of the People's Republic of Bangladesh for 2007-2008, and also supported by the Korea Research Foundation Grant (KRF-2006-F00036). A portion of this research was presented at the International Congress on Meat Science \& Technology (ICOMST), Copenhagen, Denmark held August 16-21, 2009.

\section{References}

1. Alam, M. J. (2001) Control of environmental pollution by utilizing leather industry waste. Bang. J. Environ. Sci. 7, 1120.

2. AOAC. (1990) Official Methods of Analysis. 14th ed., Association of Official Analytical Chemists, Washington DC, USA.

3. Banerjee, G. C. (1992) In poultry. 3rd ed. Oxford and IBH publishing Co. Pvt. Ltd. New Delhi, Bombay, Calcutta, India.

4. Blazej, A., Galatik, A., and Minarik, A. (1969) Zpusob izolace 
bilkovinove hmoty zodpadnich kozeluzskych louzicich lazni (The Method of Protein Mass Isolation from Tanning Lime Liquors), CSP 137077.

5. Bligh, E. G. and Dyer, W. J. (1959) A rapid method of total lipid extraction and purification. Ca. J. Bioch. Phys. 37, 911917.

6. Brown, A. H., Camfield, P. K., Rowe, C. W., Rakes, L. Y., Pohman, F. W., Johnson, Z. B., Tabler, G. T., and Sandelin, B. A. (2007) Effect of beef growth type on cooking loss, tenderness, and chemical composition of pasture-or Feedlotdevelop steers. Asian-Aust. J. Anim. Sci. 20, 1746-1753.

7. Cenni, B. and Verita, P. (1976) Hydrolysates of leather in the feeding of broilers. Zootecnicae Nutrizione Animal. 2, 213216.

8. Charles, D. D. and Johnson, E. R. (1990) Live weight gains and carcass composition of steers on four feeding regimes. Aust. J. Agri. Res. 26, 407-413.

9. Cunnif, P. A. (1998) Official methods of analysis of AOAC International ( $6^{\text {th }}$ ed.). Association of official analytical chemists, Arlington.

10. Desjardin, V., Bayard, R., Lejeune, P., and Gourdon, R. (2003) Utilisation of supernatants of pure cultures of Streptomyces thermocarboxydus to reduce chromium toxicity and mobility in contaminated soils. Water, Air Soil Pollut. 3, 153160.

11. Gill, S. A., Chowdhury, S. M., and Hossain, Z. (1992) Comparative study on the effects of protein from meat processing for broiler ration. Int. J. Agric. Sci. 28, 26-27.

12. HMSO-England. (1994) Department of Health. Nutritional aspects of cardiovascular disease: HMSO, pp. 37-46. (Report on health and social subjects, 46).

13. Hossain, M. J., Huque, K. S., Chowdhury, S. A., and Kamal, A. H. M. (1998) Use of leather shavings as an alternative to fishmeal for cattle and poultry in Bangladesh. Research Report, Personal Communication. Bangladesh Livestock Res. Institute, Savar, Dhaka.

14. Huque, K. S., Chowdhury, S. A., Hossain, J., and Kamal, A. H. M. (1992) Use of leather shavings as an alternative to fishmeal for cattle and poultry in Bangladesh. Bang. J. Livestock Res. BLRI, Savar, Dhaka, pp. 37-52.

15. Kushak, R. I., Travid, I. L., Basova, N. A., Yukhno, E. N., Filipchenkova, L. P., Isidorov, G. E., and Val'dman, A. R. (1990) Effectiveness of different doses of fish protein concentrate in feeding of chickens. Dolady Vsesoyuzhoi Ordena Lenina I ordena Trudovogo Krasnogo Znameni Akademii Sel' skhozyaistvenny auk in. V.I. Lenina. No. 6, 51-54.

16. Moreira, F. B., Prado, I. N., Souza, N. E., Matsushita, M., Mizubuti, I. Y., and Macedo, L. M. (2006) Energy supplementation on meat chemical composition and fatty acids of steers grazing black oat pasture. Seminar presented to the IcOMST, Brazil. 2, 7299-7306.

17. Muller, L. (1987) Normas para avaliacao de carcacas e concurso de carcacas de novilhos. Santa Maria: Imprensa Universitaria. pp. 31.

18. Nedopil, F., Koueky, M., and Zivocisna, V. (1975) Use of tannery lye protein in complete feed mixture for broilers. Poult. Abst. 20, 413-421.

19. Padre, R. G., Aricetti, J. A., Gomes, S. T. M., Goes, R. H. T. B., Moreira, F. B., Prado, I. N., Visentainer, J. V., Souza, N. E., and Matsushita, M. (2007) Analysis of fatty acids in Longissimus muscle of steers of different genetic breeds finished in pasture systems. Livest. Sci. 110, 57-63.

20. Padre, R. G., Aricetti, J. A., Moreira, F. B., Mizubuti, I. Y., Prado, I. N., Visentainer, J. V., Souza, N. E., and Matsushista, M. (2006) Fatty acids profile, and chemical composition of Longissimus muscle of bovine steers and bulls finished in pasture system. Meat Sci. 74, 242-248.

21. Prado, I. N., Moreira, F. B., Matsushita, M., and Souza, N. E. (2003) Longissimus dorsi fatty acids composition of Bosindicus and Bos indicus X Bos taurus crossbred steers finished on pasture. Braz. Arch. Biol. Tech. 46, 606-608.

22. Raju, A. A., Rose, C., and Rao, N. M. (1997) Enzymatic hydrolysis of tannery fleshings using chicken intestine protease. Anim. Feed Sci. and Tech. 66, 139-147.

23. Rao, D. V. R. P. (2000) Solid waste management. A project of UNIDO. Prakash Feed Mills. Personal communication. Kancheepuram, India. pp. 3-18.

24. Richard, A. A., Noella, A. B., and Marilyn, M. P. (1992) Dietary chromium intake. Biol. Trace Element Res. 32, 117122.

25. Salam, F. M. A. and Billah, S. M. R. 1998. Leather Industry: Environmental Pollution and Mitigation Measures. Society for Environment and Human Development (SEHD), 44/8 West Panthapath ( $2^{\text {nd }}$ floor), North Dhanmondi, Dhaka-1205, Bangladesh, pp. 1-68.

26. Scott, M. L., Neshem, M. C. and Young, R. J. (1976) Nutrition of the Chicken. Chapter eight. 2nd ed. Published by: M. L. Scott and Associates, Ithaca, New York, USA.

27. Singh, R. A. (1990) In: Poultry production. 3rd ed. Kalyany publishers, New Delhi, India.

28. SPSS. (1999) SPSS 7.5 software for windows, SPSS Inc., Chicago, IL, USA.

29. Tikhonovskaya, N. D. and Snitsar, A. I. (1992) Use of fishmeal with protein concentrates in the diet for broiler chickens. World's Poult. Assoc., Netherlands. pp. 620-621.

(Received 2009.12.14/Revised 1st 2010.3.19, 2nd 2010.3.10, 3rd 2010.3.17/Accepted 2010.3.17) 